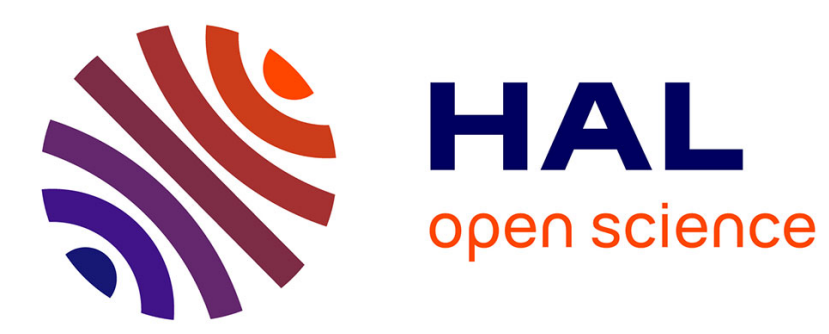

\title{
Firms, the Business Ethics and Society: from an academic to a protestant standpoint
}

\author{
Bertrand Vergniol, Yvon Pesqueux
}

\section{To cite this version:}

Bertrand Vergniol, Yvon Pesqueux. Firms, the Business Ethics and Society: from an academic to a protestant standpoint. $8^{\circ}$ Conference EBEN - European Business Ethics Network, Sep 1995, Twente, Netherlands. hal-00480877

\section{HAL Id: hal-00480877 https://hal.science/hal-00480877}

Submitted on 5 May 2010

HAL is a multi-disciplinary open access archive for the deposit and dissemination of scientific research documents, whether they are published or not. The documents may come from teaching and research institutions in France or abroad, or from public or private research centers.
L'archive ouverte pluridisciplinaire HAL, est destinée au dépôt et à la diffusion de documents scientifiques de niveau recherche, publiés ou non, émanant des établissements d'enseignement et de recherche français ou étrangers, des laboratoires publics ou privés. 
H.E.C. School of Management

Yvon PESQUEUX

Professeur-associé

1 avenue de la Libération

78351 JOUY EN JOSAS Cédex

Phone : $\quad 33139677218$

FAX : $\quad 33139677086$
Fédération Protestante

M.I.R.P.

Bertrand VERGNIOL

Secrétaire général

47 rue de Clichy

75009 PARIS

33148749092

33142814001

\section{FIRMS, THE BUSINESS ETHIC AND SOCIETY: FROM AN ACADEMIC TO A PROTESTANT STANDPOINT}

\section{INTRODUCTION}

A firm's role in society is similar to that of other social institutions: it creates meaning for the people comprising it; in other words it organizes their aspirations and lends significance to their actions. With the decline of traditional social institutions (the state, the church, the school...), as conveyors of meaning, the firm emerged as the cradle of a nex ethical system: indeed it became something of a social model. This development reached a peak in the 80's.

The last few months have seen such a deterioration in the job situation that the firm has lost its claim to ethical superiority as well as society's goodwill. Where does the firm stand today in relation to the other actors? Is a new social model in the making? 


\section{PROTESTANTISM IN THE BUSINESS WORLD}

\section{A. Max Weber's hypothesis}

\section{a. The image of responsibility}

The image one generally has of Protestantism's influence on business is that of a philosophy inculcating responsibility and good business sense. The studies carried out by the sociologist Max Weber in the early part of the century show that in the 17th and 18th centuries Protestants firms applied radically new ideas emanating from 16th century Reformation which perceived work as a field for the performance of religious duties. The production of wealth, trade, money, etc... were as important in religious terms as the social structures established by the Catholic Church.

Max Weber analysis in "The Protestant Ethic and the Spirit of Capitalism"1 gained widespread appeal. The moderate Pan-Germanism of his views enabled his theories to be applied to England, the United States and even France. The hypothesis of religious determinism, however, requires fuller treatment as the Reformation was just one of many factors behind the rise of capitalism. In the case of France, the property rights etablished by the revolution played an equally important role in the growth of capitalism.

\section{b. The primacy of Property Rights}

One of the chief characteristics of France's business tradition is the primacy of property rights. These rights, which date back to the French Revolution, were largely responsible for nurturing the French tradition of individualism. Based on the right of inheritance, they established the principle of equality between all heirs. They gave French democraty and society its individualistic economic features, which persisted well into the 1950's: small agricultural holdings, small businesses, small-scale industry, and protection of an estate independence. They contributed to the rise of France's industrial giants after the industrial revolution. The firm was a stage were such rights were exercised: to a point where the people lost their political rights within the firm and only recovered them after work.

\footnotetext{
${ }^{1}$ Max WEBER : L'éthique protestante et l'esprit du capitalisme, Presses Pocket, collection Agora Paris 1993
} 


\section{c. The tradition of public service}

The handful of entrepreneurs who spearheaded the industrial revolution in France gradually transferred the running of their firms to 'administrators'. This move was greatly facilitated by the well-organized administrative service in place since the late 17th century. France has had a smooth running department of civil engineering since the 18th century. In 1794, a public work school was set up to prepare civil, mine and military engineers. It was named Ecole Polytechnique in 1795. A network of "grandes écoles" was put in place to provide the state with the military and technical administrators it needed. These administrators were entrusted with the job of running both the public service and private sectors. The practice of moving from the civil service to the private sector dates back to this period and sprang from the need to administer government as well as company business.

\section{B. Protestant agencies in the business world: the case of Mission dans l'Industrie de la Région Parisienne (M.I.R.P.)}

The Mission dans l'Industrie de la Région Parisienne is an agency of the French Protestant Federation. Its task is that of promoting the spread of socio-economic ideas within the protestant movement and encouraging ethical debates within the business community.

It has two main functions:

a. To provide moral instruction for people involved in the management of the economy, including company executives, trade union officials and civil servants.

b. To study economic affairs and developments by taking into account the views of the actors concerned.

A characteristic feature of the Protestant approach is to integrate people's life experience into the analysis. Care is taken not to discuss unemployment without taking into account the past or current experience of the jobless, or women's work among men only, or the situation of working people without hearing workers' viewpoint, or decision making problems without the participation of managers, etc...

Organizations that act as conveyors of meaning make a vital contribution to ethical debates and the way in which jobs are distributed in society. Protestant agencies, in particular, play an active role in this regard within the business community. 


\section{THE FIRM: FROM AN ACADEMIC TO A PROTESTANT STANDPOINT}

\section{A. Benchmarks}

In his book 'Image of organization'2, G. Morgan underlines the importance of metaphor in understanding and explaining the life of an orgaization. The metaphor we use here likens a firm to a community (a group with common objectives).

Setting up a company involves pooling the requisite resources and skills to achieve common goals, such as the elimination of scarcity through the production of goods and services to satisfy demand, the transformation of input into output and the creation of value-added (model of the process-orientated firm); or the search for profitability (model of the profit-orientated firm), where profit is viewed as a reward for the risk taken by the entrepreneur.

At the beginning of the industrial revolution, the level of demand was such that an enterprise could be geared to high-volume production. Accordingly, managerial decisions in this period focused on increasing output. This trend culminated in Taylorism. As local markets became increasingly saturated, companies were forced to look for new outlets. This paved the way for the emergence of a worl market. Companies were on the look-out for any market where their products still had economic value. One strategy involved securing a monopoly position. But as this undermined social cohesion, it quickly came up against a number of legal barriers. Another strategy for preserving economic value involved introducing new products better suited to the needs of customers. The second strategy sprang from the first and came on the scene much later. It took the form of sales policies that sought to identify new market niches and quality control policies. Today, indeed, companies spend a great deal of energy bringing out 'new' goods and services.

In his book 'Ethique et entreprises'3, Jean Moussé describes the characteristics of a firm as an ethical space, albeit a specific ethical spaces:

- a firm forms part of the wider economic environment and its ethical rules are mainly related to work procedures;

- the firm's ethics are based on a set of temporary rules and, consequently, have no claim to universality;

- changing firms involves changing one's ethical space and, therefore, one's ethical rules.

One way to approach ethical issues in a firm is to see decisions taken at different levels as having an ethical dimension. Taking a decision involves, in some way, referring to a set of moral rules governing the business environment. The ethics of a decision are personal but their field of application, the firm, gives them a special significance.

The perception of a firm as an ethical space cannot be dissociated from the broader concept of corporate culture. Viewed here as a pre-established mode of conlict resolution ${ }^{4}$, it might be

\footnotetext{
2 Gareth MORGAN : Images of organization, Presses de l’Université de Laval, Editions ESKA, Québec 1989

3 Jean MOUSSE : Ethique et entreprises, Vuibert, Paris 1993
} 
tempting to define corporate culture in terms of a code of rules legitimized and administered by the company. But this would be somewhat simplistic, for it ignores that corporate decisions are heterogenous in nature, that the decisions differ according to rank and position of the decision maker and that consequently, people's ethical impact in a firm differs accordingly. Moreover, when it comes to executing a decision, the principle of justice, whose ethical implications are as important as those of the principle of seniority (ethical responsibility), prevails. Ethical differences in a company are based on whether the interest are immediate or not, individual or collective as well as on person's rank and physical location. All these factors make the firm an ethical space, exposed to the interplay of private and public interests

\section{B. A socio-economic approach of business}

\section{a. The firm as generator of economic value}

Most people today regard the firm as a social organism whose aim is to create and distribute value added. Its ability to satisfy material needs lends it a new dimension. However, the march toward an affluent society has triggered a crisis in its wake. The sole concern of today's managers is with achieving productivity gains and volume flexibility. In this context, human labour becomes the main victim of cost-cutting. There is a corresponding shift to automation. Job shedding is seen as the best way of reducing overheads as well as the number of people with whom profits have to be shared.

The innovation race produces superfluous goods that fulfil artificial needs. The tendency today is to design products and services without regard for their utility or the needs they might fulfil. As T. Monod'5 points out: 'Rather than pursuing some reasonable or worthwhile purpose, man today makes things not because they are useful, but because they can be made... The commodity, the firm and the machine... have become an end in themselves'.

\section{b. The firm and social organization}

There are two types of economic activity:

- Those relating to social organization;

- Those relating to the multiplication of scarse commodities.

Enterprises, whether public or private, set up to perform tasks relating to social organization are expected to conform to various cultural standards. Both the way in which they operate and the cost of their servcices are controlled by society. The second set of activities concerns the production of goods and services. These are owned by the firm and sold at a price the buyers are prepared to

\footnotetext{
${ }^{4}$ Janusz BUCKI \& Yvon PESQUEUX : Culture, maîtrise, liberté - convergence des buts, cahier de recherche du groupe HEC n ${ }^{\circ} 417 / 1991$

5 Théodore MONOD : $\underline{\text { Sortie de secours, }}$ Seghers, Paris 1991
} 
pay. The firm controls the conditions of exchange and defines the rules of distribution as well as the underlying 'common' purpose of the organization to which it and its customers belong.

According to E.Faber ${ }^{6}$, companies seek to transform people into producers and consumers by appropriating their time. In fact, there is a concerted ideological attempt to use social ideals to promote economic values.

This ideological offensive takes two forms:

- it exacts greater productivity, efficiency and competitiveness from staff;

- it encourages society to consume.

A company aims to maintain value added and, by implication, its own economic value. A society, on the other hand, aims to reduce scarcity and develop its potentialities trough the acquisition of knowledge, space exploration, the consolidation of social benefits, etc... As long as the eradication of scarcity cconstitutes the primary aim, the exchange model of wealth distribution is considered fair. It has, moreover, been internalized by society. From this standpoint, labour represents an economic value. In a supply saturated market, maintaining the economic value of the company and preserving the economic value of labour are antagonistic aims. When the two are in perfect equilibrium, a company's economic value can grow no further.

In the affluent society, such a situation is likely to produce the following side-effects:

- disillusionment with the government's economic and social policies because of its inability to maintain the balance between the economic value of the company and that of labour,

- social disintegration resulting from the erosion of the principles of wealth sharing and of society's very raison d'être,

- awareness of the need to redefine society's goals and mobilise the actors concerned.

\section{c. The economic constraints on firm}

Firms that supply goods for which demand has been satisfied lose their economic value. There are usually two ways of dealing with a company in trouble:

- that favoured by businessmen, which invoves either winding up the company or finding new markets abroad;

- that favoured by society, which involves subsidizing or nationalizing it. The problem with this approach is that it encourages protectionist behaviour.

The winding up of local enterprises accelerates the globalization of the economy - a phenomenon which, by its very nature, defies local conventions. Foreign companies that gain access to a market thus abandoned increase their economic value, while the host country loses control over how earnings are distributed. The world market also becomes the yardstick by which to measure the economic value of labour. The host country starts to lose its know-how and, over time, becomes dependant on foreign producers. Subsidization and nationalization, while tending to preserve a country's independance, undermine industry's economic value. They spawn rules and regulations

\footnotetext{
${ }^{6}$ Emmanuel Faber : Main basse sur la cité, Hachette Pluriel, Paris 1992
} 
intended to manage the relation between supply and demand. The regulation of value added weakens the link between individual effort and reward, generally perceived as the driving force behind entrepreneurship. 


\section{Firms and the social contract}

\section{a. Exclusion}

- Facts and figures:

The current economic situation reveals some home truths about our society: that it produces outcasts, and not just drop-outs and the underpriviliged. The following figures show the escalating level of exclusion: in E.U. countries, there were 38 million people registered poor in $1975^{7}, 45$ million in 1985 and 53 million in 1992. Today, one european in 7 lives below the poverty line.

- The path to exclusion:

According to Denis Clerc ${ }^{8}$, exclusion is based on two factors, both relating to employers' recruitment criteria: job experience and qualifications. Being out of a job for a long period mars the job seeker's track record. The longer a person stays out of work the more difficult it gets to find one. For reasons of flexibility firms recruit qualified people for jobs which do not require any special qualifications.

The implications of this policy are only too clear: long-term unemployment and academic failure are creating a growing body of social outcasts. Yet there is incontrovertible evidence that people who have been out of work a long time are not more prone to absenteeism when they find a job than those who have never been unemployed.

- A new phenomenon:

Studies show that one is not born poor; one becomes poor. Between 1975 and 1990, France gross domestic product grew by $70 \%$. Exclusion during this period was produced by the mismatch between society and the aspirations of its members. Unlike the poverty and exploitation of the past, the current phenomonon of exclusion entails the disintegration of social ties as a result of urbanization, geographical mobility, family instability, etc... In exploitation there was some sort of social bond for 'conflict was a mean of building social ties' ${ }^{\prime}$. The new phenomenon of exclusion, on the other hand, 'involves severing ties with people unilaterally without providing compensation or relief and has become something of a norm at all levels of society: among couples, in firms and in state institutions providing social services' ${ }^{10}$.

\section{b. The social contract}

The members of society are bound to each other by means of a social contract. 'The increasing precariousness of people's conditions of existence in society, when accompanied by cuts in social services should be condemned not only as a misguided act or mismanagement, but as a

\footnotetext{
${ }^{7}$ A poor is defined as a citizen having less than the half of the average income

${ }^{8}$ Directeur de la revue Alternatives Economiques, dans un article paru dans Manière de voir $n^{\circ} 20$, novembre 1993

9 Alain TOURAINE : Interview à Libération, 12/02/1993

10 Jean Baptiste de FOUCAULD, Le Monde 16/3/1993
} 
violation of the social contract - and its principles of liberty, equality, fraternity - that brands all our institutions as illegitimate'11.

To preserve a country's independance, it is necessary to devise factors of motivation, other than the redistribution of value added, capable of promoting adhesion to basic social values. The E.U. countries are attempting to do just that by seeking closer intergration, even if most of their initiatives focus on the defence of European economic values in the face of American and Japanese competition.

The prevailing economic model is founded on economic values designed to enhance productivity. When misinterpreted and carried to the extreme, these ideas lead to the supplanting of basic social values by economic values perceived as an end in themselves. This practice is reinforced by 'populist theories'. The argument goes that in the buying/selling mode of distribution, economic value alone provide access to the resources enabling individuals and collective aspirations to be fulfilled. These theories urge people to accumulate commodities and are legitimated by the language used in business circles.

11 Jean Pierre MOLINA : Justice sociale, Royaume de Dieu, Europe, Mission dans l'Industrie, juin 1993 


\section{THE ETHICAL DEMAND OF FIRMS}

\section{A. The most common scenario}

\section{a. From diabolisation of business to identification with it. The divorce between business and society: the firm beseiged by ethical demand}

In the space of few years French society changed from rejecting business to worshipping it. But the charm has almost worn off today. After a somewhat involuntary rehabilitation, business became a revered conveyor of values in the French social imagination. Some even saw it as the last bastion of moral edification.

Today confidence in the role of business has all but evaporatedd: people feel that the sacrifices made during the 80 's to modernize the economy did not bring the promised long-term benefits. A'divorce' 12 has taken place between firms and their employees, who have lost confidence in the former ${ }^{13}$. Gone are the days when the business ethic inspired confidence in management. Even if there is an economic upturn, people have no grounds for believing that it will lead to more jobs, clearly the most important popular yardstick of socio-economic performance. The future is no longer synonymous with progress, now perceived in terms of social integration. As Michel Bon put it in a report written for the Institut de $1^{\prime} E n t r e p r i s e^{14}{ }_{2}$ 'Integration becomes a major issue whenever there is social unrest'.

\section{b. Market economics as a substitute for ethics}

The market economy is widely seen as the only viable, indeed logical, economic system today. 'As there are no suitable alternative to it, the only way the existing system can be improved, and its purely economic logic confronted, is through ethics' 15 .

The French model of liberalism is a mixture of market forces and the social sharing principle, 'a mixed regime in which the excesses and shortcomings of market mechanisms are corrected through state intervention'16, through partial redistribution of income, education, research, etc... We are the products of the antagonistic yet compementary relationship between the advocates of liberalism and those of socialism, of the tension between an existing reality - the market economy - and a messianic version - socialism.

The advocates of liberalism à la Adam Smith believe that in a market economy the sum of individual interests produces economic growth and 'naturally' works in favour of the common

\footnotetext{
12 L'expression est d'Alain LEBAUBE, Le Monde, 14 avril 1993

13 interrogés sur la santé de leur entreprise, $77 \%$ des salariés considèrent qu'elles vont bien et $73 \%$ estiment que les entreprises "profitent de la crise pour licencier alors qu'elles n'ont pas vraiment de difficultés".

14 Michel BON : Les attitudes devant le travail, Institut de l'Entreprise, septembre 1993 p.24

15 Olivier ABEL, philosophe, Document MIRP

16 Alfred GROSSER, Le Monde 15 avril 1993
} 
good. This is the mechanism of the invisible hand: 'It is not through the benevolence of the butcher, brewer or baker that we await our inner but through the pursuit of their self interest' ${ }^{17 .}$ Can the market transform the competition between individual interests into social harmony?

For the advocates of social sharing, 'human nature being what it is... christian (but not only them) have to introduce corrective mechanisms: otherwise the world will become an impossible place to live in for a great many people' 18 .

Whatever the trends, French society cannot function on market forces alone. This is what most people feel and the reason why they are seeking, overtly or covertly, to give greater priority to ethical issues.

\section{c. The increasing complexity of the businees world: the ethic of responsibility}

The third reason advanced for enhancing ethical awareness in business is that industrial activity is becoming increasingly complex, that the economy is based on a closely-knit network of businesses, that firms are interdependent, and that the real assets of a business are intangible. The exponents of this view go on to assert that in the face of such complexity responsibility alone allows economic players to act in a meaningful way within the local environment.

To validate the ethical argument advanced by managers, it is necessary to study two phenomena:

- The first is the real distribution of jobs by branch of activity and socio-economic group and how many employees are actually affected by the changing job situations;

- The second is what the employees themselves feel about acquiring increased responsibilities, it being understood that people do not take on more responsibilities without agreeing to do so or against their will. Since no such study has, to our knowledge, been carried out, we cannot but endorse the view that 'work should no longer be viewed independently of a conscious adhesion to the objectives pursued through collective action and should be seen as a factor of progress not regression. A citizen's commitment is more honorable than that of a mercenary' ${ }^{\prime 9}$. It is better to employ a citizen than a mercenary... Few would disagree with such a view.

In the late 20th century, employees are being called upon to take on greater responsibilities in much the same way as the people of Israël were under the Law of Jubilee (Leviticus 25) in 6 $\mathrm{BC}^{20}$. Responsibility, however, can only become an ethical norm if people practice what they preach. A firm is a hierarchical structure, dependent on the market and its shareholders. Conditions are not always favourable for the exercise of responsibility. When this is the case, it is better not to

\footnotetext{
17 Adam SMITH : La Richesse des nations, 2 tomes, Garnier Flammarion, Paris 1991

18 Jacques BLANC : Construire un monde solidaire in Réforme $\mathrm{n}^{\circ} 2476$

${ }^{19}$ Hubert LANDIER, consultant, MCS n ${ }^{\circ} 375$

20 "un système qui représente une recherche considérable dans le domaine de la gouvernabilité, mais qui ne peut aboutir que sur la base d'une foi partagée" Jean-Pierre MOLINA, bibliste de la Mission Industrielle de la Région Parisienne
} 
talk of ethics as this only diminishes its value. In other words, the notion of responsibility is either translated into practice or it becomes, like religion before it, the opium of the people, and ethics becomes an object of derision or means of manipulation.

One cannot talk about the responsibilities of employees without talking about the responsibilities of firms: how and who do firms recruit? This covers not only the mode of recruitment, or 'decruitment'21(layoffs), but also the social responsibilities of the 'civic firm'. There is already the example of recruitment premiums to promote employement of young people and the long-term unemployed. The development of a recruitment policy in favour of people having difficulty finding a job is surely one way of linking effectiveness and ethics in the long run. Responsible employees and social investment go hand in hand.

21 le terme "décrutement" renvoie bien évidemment aux compressions de personnel. Daniel LABBE, responsable syndical de Renault, parle ainsi de "décrutement curatif" en évoquant la fermeture du site de Boulogne-Billancourt 


\section{B. The loss of social bearings and the rise of ethical demands}

If ethics has pervaded the business world, or if firms have recently been paying particular attention to it, it is not out of self-interest alone. The development of ethics is the result of farreaching societal changes. There are four ideological factors at work here.

\section{a. The secular culture under fire}

The establishment of a secular culture is one of the chief achievments of the Third Republic, one of the basic tenets of the Declaration of the Rights of Man (preambule to the French Constitution) and a cause to which Victor Hugo devoted his life. The principle of secularism is under fire today because the very future of French society is uncertain. State education, the principle conveyor of secular culture is no longer the locomotive of social progress or the provider of equal opportunity for social promotion. Unemployment has eroded its credibility.

The question uppermost in people's minds is whether firms can provide proper vocational training in place of schools.

\section{b. From Morality to Ethics}

In France today, religious morality is taken with a pinch of salt. To quote Jean Delumeau ${ }^{22}$, christianicy 'must take into account people's desire for participation, a desire which pluralist democraty embodies politically. The absence of a real dialogue between the faithful and Rome is so glaring that it tarnishes catholicism's image in the eyes of the public'. One has only to see the scepticism with which the Catholic Church's views on sexuality are greeted. Briefly, morals are a set of external constraints whereas ethics is a personnal force. Rules today are ususally produced by the people themselves: that is why we prefer to use the word 'ethics' rather than the term 'morals'. Both ethics and morals imply freedom of action and the existence of conditions for its exercice. Paul the Apostle put it with evangelical clarity: 'I can do anything I like, but there are things I don't want to do. I can do anything I like but I shall not be enslaved by anything'23. Ethics seek to ally analysis and values: 'it is a code of conduct and search for direction and meaning' 24 . French society no longer accepts external commandments as a guide to behaviour.

Can't the firm - a place for the production of wealth, a place of discipline, effort and communion - provide strong ethical guidance for the whole of society?

\section{c. The fall of Communism and its utopia}

'During the cold war - the specific war between Capitalism and Communism - the issue of business and market morality did not feature much. Capitalism was good because it was anti-evil.

\footnotetext{
22 Le Monde, 15 décembre 1993

23 Première épitre de Paul aux Corinthiens, chap. 6, verset 12

${ }^{24}$ Hugues PUEL : l'économie au défi de l'éthique, Cujas/Cerf, Paris 1989, p.9
} 
But with the demise of Communism everything has changed. Now the sole system and with no enemy to confront, Capitalism is being forced to justify its morality' ${ }^{25}$. The surge of interest in ethics in French society and in the business world alike may well be the result of the fall of the Iron Curtain and the loss of influence of the French Communist Party! For socialists, French Society has been shaped by 'social progress' and the promise of a brighter future. Political institutions were considered the most efficient vehicles for guiding society towards greater freedom, justice and happiness. But with the future looking increasingly grim and political institutions increasingly ineffectual, people are at a loss what social system to go or in what area to make a social contribution.

The question that comes to mind is whether the firm can serve as a receptacle for the production of wealth, a sense of community, individual development etc...

\section{d. The myth of the technological fix}

The myth of the technological fix ${ }^{26}$ generated by scientific progress seems increasingly out of place because of its reliance on quantitative explanations and its blind worship of work. In fact, whenever science solves a problem, it discovers or creates a new one. This raises the question of how far should science be allowed to go. People no longer have blind faith in science. In a society where progress for the sake of progress is no longer seen as a moral imperative, there is a great need for firms to have a set of ethical rules that mark their field of action off and enable them to play a more meaningful role.

\section{CONCLUSION : THE CONSTRAINTS ON FIRMS}

We can identify four factors that have changed French society and that largely account for the development of the business ethic in this country. Basically, the firm could replace the school, the family and the church as the social institution that conveys meaning. The business ethic is not only a new managerial culture or an internal need for more responsibility; it is also a new social model that offers opportunity for investment, a future, identification... in short, a new religion.

The firm should not only be a community of winners; it should also include the losers produced by relentless competition, economic chaos and social confict. Can the firm over time serve as a social model in the collective imagination, even though reality (as for all social models) does not correspond with the image? This is clearcly not the case today. As we mentioned earlier, we are currently witnessing a rupture between the firm and society. After having been diabolized and then deifed, the firm once again finds itself rejected.

\footnotetext{
25 André COMTE-SPONVILLE : le capitalisme est-il moral ? L'Expansion Janvier 1992

${ }^{26}$ L'expression est de Jacques ELLUL. Voir en particulier chez cet auteur La technique ou l'enjeu du siècle, Armand Colin, Paris 1954 et le système technicien, Calmann-Lévy, Paris 1977
} 
The chairman of a big national enterprise, speaking at a conference organized by the Protestant Service in the business world, described the firm thus: The firm is a special community (and not a general community like the nation or the family) whose aim is to place commodities on the market as efficiently as possible; the firm is a non-independent community as it is directly dependent on the market (the least expensive commodity is bought) and its shareholders (who lay down its financial policy); the firm is an undemocratic community for its managers are not picked by a democratic procedure; but like the state it has centres of power and conter-power.

We may therefore conclude from this business leader's speech that the business ethic is first and foremost an ethic of efficiency. The more civilized a society the more ethically aware the firm within it. It is not the job of the firm to create morality for the rest of society, as only free and democratic public institutions are in a position to do so. It is as much the duty of political institutions to lay down moral rules as it is the duty of companies to observe them and respect the public interest with which they are intimately bound up. 